\title{
Effects of Customer Relationship Management on Product Innovation in Nigeria. A Case Study of Xerox HS Nigeria Limited
}

\author{
Michael Oyenuga ${ }^{1}$, Ruth Angbazo Andah ${ }^{2}$, Marcus Garvey Orji ${ }^{1}$, Alice Ukeh Agabi ${ }^{1}$ \\ ${ }^{1}$ Department of Business Administration, Veritas University, Abuja, Nigeria \\ ${ }^{2}$ Department of Business Administration, Nasarawa State University, Keffi, Nigeria
}

\section{Email address:}

oyenugam@veritas.edu.ng (M. Oyenuga), ruthandah68@gmail.com (R. A. Andah), marcusorji@gmail.com (M. G. Orji), alysagabi.aa@gmail.com (A. U. Agabi)

\section{To cite this article:}

Michael Oyenuga, Ruth Angbazo Andah, Marcus Garvey Orji, Alice Ukeh Agabi. Effects of Customer Relationship Management on Product Innovation in Nigeria. A Case Study of Xerox HS Nigeria Limited. American Journal of Theoretical and Applied Business.

Vol. 5, No. 4, 2019, pp. 113-126. doi: 10.11648/j.ajtab.20190504.15

Received: October 9, 2019; Accepted: November 12, 2019; Published: November 26, 2019

\begin{abstract}
Customers generally are regarded as king in every business and they should be treated as such. In doing so, an organization is expected to get close to them and treat them well. The study was carried out to determine the effects of customer relationship management on product innovation in Nigeria, with emphasis on Xerox H. S Nigeria Limited. The research design adopted was survey research. The population of the study consisted of 83 staff drawn from Lagos and Abuja Offices of the Company. Primary data were sourced through self-administered questionnaires, and the formulated hypotheses tested using Pearson Correlation (r) and multiple regression. The findings revealed that customer information management has significant effect on product innovation, and that there is a significant effect of customer value management on product innovation. Also, multi channel management have significant effect on product innovation. The study recommended among others that organizations make customer relationship management a priority so as to have adequate product innovation, also when designing and implementing a multi channel strategy, objectives and goals of internal and external parties affected by the multi channel approach should be considered.
\end{abstract}

Keywords: Customer Relationship Management, Product Innovation, Customer Information Management, Customer Segment Value Management, Multi-Channel Management

\section{Introduction}

Over the last decade, too many organizations have assumed that their products or services were so superior that customers would automatically keep coming back for more. Their believe generally was that, once products or services were better off than those of the competitors, irrespective of other variables, customers would always come back for more.

This assertion may not be true afterall because businesses should be able to maintain and sustain a long term mutually beneficial relationship with their customers besides having quality products. This seems to align with the universal adage that says 'The Customer is King' [1]. As a matter of fact, it is virtually impossible for any business to thrive without customers which explains the importance businesses attach to the relationship that exists between them and their customers [2].

Many researchers have noted that customers are the reasons for any business set up and that any business exists in order to serve customers or meet their needs either immediately, in the short term or in the long term [3, 4]. In capitalist economies such as those of North America, Great Britain, Western Europe and other parts of the globe, the customer is for all intents and purposes regarded as the 'King' [1]. The founder of Wal-Mart, Sam Walton attempted to answer a question that says: "Who is the real boss?" $\mathrm{He}$ said, "There is only one boss, the customer, and he can fire everybody in the company, from the chairman on down, simply by spending his money somewhere else" [5]. 
The adages and comments created by researchers and commentators alike to express the relevance of the customer places the customer above every other person or object in the business arena. This is because the customers do not only create the demands for products and services but also purchase them. As exchange and transactions continue to take place between two parties, a relationship that is beneficial is automatically created. Murcko [6] argued that 'for most business organizations, $20 \%$ of the customers generate $80 \%$ of their profits. Those companies would often be better off by focusing more on that $20 \%$ and by searching for other customers similar to that $20 \%$ and focusing less on the other $80 \%$ of their current customers. For the customers, their needs are easily identified by the company, value is gained for money spent and satisfaction is derived [3].

These facts have explained and attracted reasons why the relationship that is created or that exists between the providers of goods and services and the receivers, users or consumers of such goods and services should be closely monitored, highly maintained and effectively managed in order to retain the current customers and further expand the customer base [1].

Globally, Customer Relationship Management (CRM) has been one emerging and recognized strategy that many business organizations adopt in order to derive success and achieve competitive advantage [7]. In order to compete effectively in today's marketplace, organizations must change their strategy to become more customer focused, not product focused. Customer Relationship Management (CRM) is the best way to integrate this customer-facing approach throughout an organization [8]. The root of CRM stems from the relationship marketing theory and was first coined during the 90 s originally to maintain contact and communication with customers [9]. According to Boateng [10], the generally accepted purpose of CRM is to enable organizations better serve their customers through the introduction of reliable processes and procedures for interacting with those customers'. Apart from this, CRM is often thought of as a strategy that enables organizations improve in number of areas. It allows businesses understand the customers very well (as well as their need and wants), retain existing customers through better customer experience; attract new customers, win new clients and contracts, increase profitability and decrease customer management costs [7]. Knowing how important they are, customers, if well related with, should also play important part in product innovation. CRM could be employed to systematically leverage customer-related information to enhance product innovation [11].

Product innovation has been recognized as a primary means of corporate renewal [12], and as an 'engine of renewal' [13]. For many organizations, creating new products is a central path by which they adapt and sometimes even transform themselves in changing environments [14, 12, 9], Hewlett-Packard transformed from an instruments company to a computer based one through product innovation. Similarly, Intel changed from a memory company to a microprocessor firm through product innovation [15], Thus, in the face of intense international competition, rapid technology evolution, and customers' maturing expectations, product innovation is a primary way in which firms actually adapt.

This study therefore seeks to find out the effect of customer relationship management on product innovation in Nigeria.

\subsection{Statement of the Problem}

Customer relationship management is increasingly important to firms as they seek to improve their profits through longer-term relationships with customers. Customer relationship management is a core organizational process that focuses on establishing, maintaining, and enhancing longterm associations with customers [16].

Organisations, in their quest to improving profits, should also be aware that they need to embark on product innovation. However, many of them believe that customers are only interested in superior products and low prices [17], only about $30 \%$ of organizations surveyed had a different notion and lay emphasis on product innovation because as the world changes, so the taste of customers.

Customer relationships have been increasingly studied in the academic marketing literature [18-21]. An intense interest in customerrelationships is also apparent in marketing practice and is most evident in firms' significant investments in customer relationship management (CRM) systems [1719]. Relationship marketing scholars have long advocated that pursuing long-term relationships with customers instead of a transaction oriented approach is more profitable for firms [20]. Prior studies have found an equivocal impact of CRM on firm performance [21, 22]. Payne and Frow [23] have viewed CRM from the point of customer information management, customer segment value and multi-channel management. One possible reason for these ambiguous empirical findings is a lack of understanding of the mechanisms that link CRM with innovation. Boulding et al. [21] reviewed the existing literature on CRM and identified potential pitfalls such as lack of technical know-how and unknowns in CRM implementation. Previous studies on CRM have focused on analyzing how customer acquisition, retention, cross-selling, loyalty programs, etc. affect performance [18]. The role of CRM in product innovation is either ignored or it is implicitly assumed that companies have a given product portfolio and that CRM can be effectively used to leverage this current product portfolio. Thus, while CRM is widely accepted as an effective approach to collect, analyze, and translate valuable customer information into managerial action, this potential has been investigated only in the context of existing product portfolios. The downside of this prevalent thinking in the CRM literature is that it may cause firms to produce corerigidities which could lead to long-term failure [21].

Generally, though there have been a series of research on product innovation, little has been heard about how CRM affects the subject matter thereby raising concern from 
researchers, for example, [21] state: “... this raises an interesting research question: What is the relationship between the level of the firm's CRM and its level of innovation?" The goal of the present study, therefore, is to address this important void in knowledge in this area.

The study therefore seeks to answer the following questions:

a) Does customer information management have effect on product innovation in Nigeria?

b) Does customer segment value management have effects on consumer product innovation in Nigeria?

c) Does multi-channel management have effect on product innovation in Nigeria?

\subsection{Research Hypotheses}

The following hypotheses will be tested in the course of this study;

$\mathrm{H}^{1}{ }^{1}$ : Customer information management does not have effect on product innovation in Nigeria.

$\mathrm{HO}^{2}$ : Customer segment value management does not have effects on product innovation in Nigeria.

$\mathrm{H}^{3}$ : Multi-channel managementdoes not have effect on product innovation in Nigeria.

\section{Literature Review}

\subsection{Conceptual Framework}

\subsubsection{The Concept of Customer Relationship Management}

The term "customer relationship management" emerged in the information technology (IT) vendor community and practitioner community in the mid-1990s. It is often used to describe technology-based customer solutions, such as sales force automation (SFA). In the academic community, the terms "relationship marketing" and CRM are often used interchangeably [24]. However, CRM is more commonly used in the context of technology solutions and has been described as "information-enabled relationship marketing" $[25,26]$ suggest that CRM is "a philosophically-related offspring to relationship marketing which is for the most part neglected in the literature," and they conclude that "further exploration of CRM and its related phenomena is not only warranted but also desperately needed."

Customer relationship management (CRM) is no longer something that only leading-edge enterprises use to gain competitive advantage. It is now a necessity for survival.

Customer relationship management is a complex and difficult way of doing business. Much as some would like us to believe, CRM is not just about installing software or automating customer touch points. It is about the reinvention of our enterprises around the customer. It is about becoming and remaining customer-centric.

It is worthy to note that CRM begins with the basic premise that firms view customers as manageable strategic assets of the firm [27, 28]. Moving beyond this basic concept, the customer-firm relationship has been dissected into stages and firms have attempted to manage and strategize about those relationship stages. In general terms, those stages are (29) customer relationship (re) initiation, (30) customer relationship maintenance (i.e., relationship duration management and customer value enhancement), and (2) customer relationship termination management [28, 22, 5, 23]. Extant literature reflects a consistent belief that firms should systematically engage in and learn from the customerfirm relationships that occur throughout these relationship stages. Various authors expound on these core ideas, and in doing so, derive varied conceptualizations of CRM and its practice. For example, customer learning orientation [31], interaction orientation [32], customer relationship orientation [33], key customer focus [34] and customer knowledge process [33] are variant terminologies that all relate to the basic premise of the CRM concept - customers are crucial assets that firms should learn from and manage for value. Many of these conceptualizations also accept the perspective that the customer-firm relationship evolves through three stages - initiation, maintenance, and termination.

\subsubsection{Meaning of Customer Relationship Management}

Customer relationship management, or CRM, means different things to different people. Even the meaning of the three-letter abbreviation CRM is contested. Most people use CRM to refer to customer relationship management. Others use CRM to mean customer relationship marketing [23].

Another group, in the belief that not all customers want a relationship with a supplier, omit the word relationship, preferring the term customer management $[8,35]$. Still others opt for the expression relationship marketing Henneberg [36]. Whatever it is called, CRM is clearly a business practice focused on customers.

CRM is a strategic approach that is concerned with creating improved shareholder value through the development of appropriate relationships with key customers and customer segments [23]. CRM unites the potential of relationship marketing strategies and IT to create profitable, long-term relationships with customers and other key stakeholders. CRM provides enhanced opportunities to use data and information to both understand customers and co create value with them. This requires a cross-functional integration of processes, people, operations, and marketing capabilities that is enabled through information, technology, and applications.

Customer relationship management (CRM) is a core organizational process that focuses on establishing, maintaining, and enhancing long-term associations with customers [16].

CRM is an e-commerce application [37]. CRM is a term for methodologies, technologies, and ecommerce capabilities used by companies to manage customer relationships [38]. CRM is an enterprise wide initiative that belongs in all areas of an organization [39]. CRM is a comprehensive strategy and process of acquiring, retaining, and partnering with selective customers to create superior value for the company and the customer [40].

CRM is about the development and maintenance of long 
term, mutually beneficial relationships with strategically significant customers [41]. CRM includes numerous aspects, but the basic theme is for the company to become more customer-centric. Methods are primarily Web-based tools and Internet presence [42].

CRM can be viewed as an application of one-to-one marketing and relationship marketing, responding to an individual customer on the basis of what the customer says and what else is known about that customer [43]. CRM is a management approach that enables organizations to identify, attract, and increase retention of profitable customers by managing relationships with them [44]. CRM attempts to provide a strategic bridge between information technology and marketing strategies aimed at building long-term relationships and profitability. This requires "informationintensive strategies" [45]. CRM is data-driven marketing [46]. CRM is an enterprise approach to understanding and influencing customer behavior through meaningful communication to improve customer acquisition, customer retention, customer loyalty, and customer profitability [47].

\subsubsection{Dimensions of CRM}

Based on an extensive review of the previous literature, [48] define CRM in terms of three perspectives which lie along a continuum: narrowly and tactically as a particular technology solution, wide-ranging technology, and customer centric; [36] viewed CRM from the perspectives of IT infrastructure, human analytics and business architecture. In their own work, [48] identified the dimensions of CRM to be customer information management, customer segment value management and multi-channel management. This research will simply adopt the dimensions according to the latter, this is because they take into cognizance the concept of product innovation. Initially, CRM was considered mainly as information-technology (IT) enabled customer solutions, such as sales force automation. Today, however, CRM is widely seen as a "holistic approach to managing customer relationships to create shareholder value" [23]. More specifically, this involves developing relationships with key customers and customer segments. To do so, CRM combines relationship marketing strategies and relevant technology to create profitable, long-term relationships with customers [23]. By focusing on CRM, companies acquire and use customer information which aids in both understanding and co-creating value with them.

\subsubsection{Customer Information Management}

Customer Information Management (CIM), is the process of getting bits of isolated data about customers and managing them as a whole or deploying them to places where they can do the most good. Customer information management refers to the processing of customer-related information and is an element of a firm's overall knowledge management [46]. More specifically, it involves the acquisition of customerrelated information and its dissemination within the organization as well as the organization-wide responsiveness to it $[49,48]$ showed that the existence of the customer centric information processes increases CRM performance.
Customer information management is typically done across an architecture. For instance, if staffers are crossindexing accounts to provide more readily accessible customer identifiers or names, or account histories, that would constitute CIM. In doing CIM, workers may need to deal with analyzing more structured or less structured data for example, collecting stray bits of information from Internet forums or mining customer names and numbers from letters or other print communications.

The end goal of CIM is to order all of the information that a business has about customers in any part of its software architecture, breaking down data silos, so that the business has the best intelligence and benefits the most from its data assets.

The key activity of identifying customers and their needs can be accomplished by systematically collecting and disseminating customer information [21, 48]. This knowledge can be used to develop new products that are aligned with customer requirements and create value for the firm [23]. Firms need to collect, comprehend, and use information about its customers to improve new product performance.

\subsubsection{Customer Segment Value Management}

A key aspect of CRM is to differentiate between customer segments and to customize marketing activities to these segments [22]. This is also considered to be a key component of the dual creation of value process that characterizes an effective CRM process [23]. In the context of existing products, this typically involves segmenting customers with regard to their respective sales and/or profit potential [22]. In the context of new products, however, this aspect of CRM needs to be extended. Here, the objective is to identify and to interact with the most valuable customer segments with regard to the product innovation task. The following customer segments are particularly relevant in this context.

A first segment consists of customers that provide useful information which aids the firm in carrying out product innovation tasks. So-called "lead users" are a prominent example of this type of customers with high informational value. Lead users face needs for new solutions much earlier than other customers and benefit significantly from a new product by obtaining a solution to their needs [50]. They also possess unique knowledge about future market needs and trends [51]. Lead users therefore provide valuable information for new product development. They can have new ideas for new products, develop these ideas into product concepts or even full products, and assess the commercial viability of a new product idea or concept, especially regarding its design features and its market potential $[49,50]$. Research shows that new products developed jointly with lead users are commercially more successful than new products that are not [52].

A second segment consists of customers that are economically valuable. These are customers who could potentially buy large quantities of the new product or are willing to pay premium prices. This information helps 
companies to target economically attractive market segments with their new products. Previous research indicates that aligning the product innovation process with these valuable customers' requirements increases new product performance [53].

Opinion leaders are a third valuable segment of customers for product innovation purposes. Opinion leaders occupy a central position in a relevant social network [54] and are the first to communicate experiences with the new product within their social network, which helps build consumer knowledge about the new product. This activity is important for a new product's success because it speeds up the diffusion of the new product in the market [55].

In addition to customer information management, differentiating CRM activities among customers based on their preferences and value contribution to the company is a key concept of CRM $[24,56]$. This involves all activities that help to evaluate customers and integrate information about them in organizational processes [23]. In the context of product innovation, this involves segmenting customers according to the level of value they provide to the product innovation process. This value varies across customer segments. Based on the information gotten from customers, they can be segmented according to the value they provide to the firm with regard to product innovation. In a product innovation context, value can entail economic, informational, opinion leadership, or relationship quality value to the company $[58,59,1,32]$.

Finally, the quality of relationships between a firm and its customers can have an impact on product innovation [18]. High levels of satisfaction, trust, and commitment are characteristics of high-quality, long-term customer relationships [57, 60]. Since loyal and committed customers are more willing to share their product knowledge [11], a good relationship with customers further increases the probability that firms and customers repeatedly work together in developing new product ideas, which creates joint learning effects. In addition, the firm is likely to share more detailed and confidential information with the customer that should benefit both the product innovation process and outcome.

\subsubsection{Multi-channel Management}

Multiple channel direct interaction processes are also an integral part of CRM [40, 19]. Customer interaction and integration can be understood as communication processes that support knowledge sharing between the firm and its customers [58]. Each customer contact point provides the opportunity to gain valuable information and to build a customer relationship. If information is collected and shared across multiple channels, firms and customers have the opportunity to choose an appropriate communication channel for a specific purpose. In the context of product innovation, multi-channel management allows the firm to use a variety of channels to contact different segments of customers for a specific task. Thus, multi-channel management as part of CRM increases the opportunity for a firm to collect more valuable information for product innovation from customers. Using multiple channels will therefore help to provide more detailed customer input into the product innovation process. This leads to higher new product performance on the market. Offering alternative means of communication and channels of distribution is also identified as a key CRM process, this involves the systematic integration of multiple traditional and new electronic communication channels to manage the dialog with customers $[5,23]$. In the case of product innovation, multi-channel management offers various ways to interact with customers for the purpose of generating and launching new products. Current views on CRM stress that multiple processes need to be integrated in order to be effective [21]. Multiple communication channels enable companies to collect information and interact with valued customers more effectively in a variety of ways.

\subsection{Product Innovation}

Product innovation has been recognized as a primary means of corporate renewal [61], and as an 'engine of renewal' [62]. At the same time companies have been exhorted to develop more innovative rather than incremental products, and there has been an emphasis on the development and marketing of innovative products. For many organizations, creating new products is a central path by which they adapt and sometimes even transform themselves in changing environments [63].

Product innovation is defined as the process of bringing new technology into use $[40,64]$. Product innovation can be separated into three basic categories: line extensions, me-too products and new-to-the-world products. Line extensions are products still familiar to the business organization but new to the market. Me-too products are considered new to the business organization but familiar to the market; that is imitation of competitors' products. New-to-the-world products are considered new to both the business organization and the market $[65,66]$. To reduce the risk of product failure, a business organization must develop an indepth understanding of the target market $[67,68]$ and that requires knowing the customers.

\section{Types of Innovation}

Innovation refers to the creation of a product, service or process. Innovations can be thought of as falling on a continuum from evolutionary or "continuous to revolutionary or "discontinuous". Discontinuous innovation has been discussed in a variety of ways. Terms such as "radical", "breakthrough", "revolutionary", "really new", "gamechanging" and "boundary expanding" have all been used to refer to products that involve dramatic departures from existent products or their logical extensions [69].

In reviewing literature, it is apparent that various bases have been used for determining the "radicalness" of an innovation. One reason for this may be the different perspectives that firms have respect to innovation [57] have suggested that the relative focus of innovation changes a $\mathrm{s}$ a firm matures. In their view, a firm's capacity for and methods of innovation (i.e bases of innovation) depend on the 
company's stage of evolution from a small technology-based enterprise to a major high-volume producer [70]. This underscores the fluid nature of innovation with respect to the firm and the environment in which it operates [57].

Some of the work dealing with this type of innovation argues that radicalness is a perception of organizational members and depends on the amount of experience people in the organization have with the innovation they are developing [71]. For example, [72] defined technological innovations as the degree of novelty organizations have to employ to solve the critical technical problems when developing new products. However, the principal measure of technological innovation that Nystrom used in his study reflected a more product-based view of innovation than his "company competency" based definition of technological innovation would seem to have suggested. The measure he used was based on a rating of the degree of novelty or uniqueness of the technological solutions themselves $[72,73]$ has discussed three levels of innovation: pioneering, adaptation and imitation. This scheme for categorizing innovation reflects the degree to which technology is applied in a new way and to some extent the degree to which it is based on an existing product. The three categories for defining innovativeness (high, medium and low) used by [8] are similar to the categories discussed by Crawford. Likewise, [55] suggest that the degree of change (inclusive of the degree of manufacturing process change) represented by a product is the most useful way to classify development projects. [30] discussion of pioneering or new-to-the-world products also reflects a product/technological-novelty view. Such views are consistent with [52] characterization of discontinuous innovation as the development or application of significant new technologies or ideas. [55] distinguish between "incrementally improving innovativeness" and "radical innovativeness" and explicitly exclusive commercial performance as a bases for classifying innovativeness. However, researchers such as [39] hold that discontinuous innovation, in addition to being based on new technology and aimed at a market that is unfamiliar with the product class, encompasses both the development and the introduction of the product into the market.

A useful way of representing innovation is shown in Figure 1. In it, two critical dimensions are used to delineate the various levels or degrees of innovation. Product innovation can be viewed as lying along a "Technological Capability" dimension and a "Product Capability" dimension. The technological Capability dimension refers to the degree to which the product involves expanding (technological) capabilities (the way product functions are performed) beyond existing boundaries. Discontinuous products involve advanced capabilities that do not exist in current products and can not be achieved through extension of existing technology. The product capability dimension refers to the benefits of the product aas perceived and experienced by the customers or users.

In this view of innovation, there are essentially four levels or types of innovation (excluding moderately innovative products). The first type encompasses products that utilize existing technology and provide the same benefits as existing products. Such products are continuous both in terms of the technology employed and the way they are experienced by customers. Although they may be new, they are not innovative. In addition to continuous new products, new products may be discontinuous with respect to technology, the benefits perceived by the customers or both.

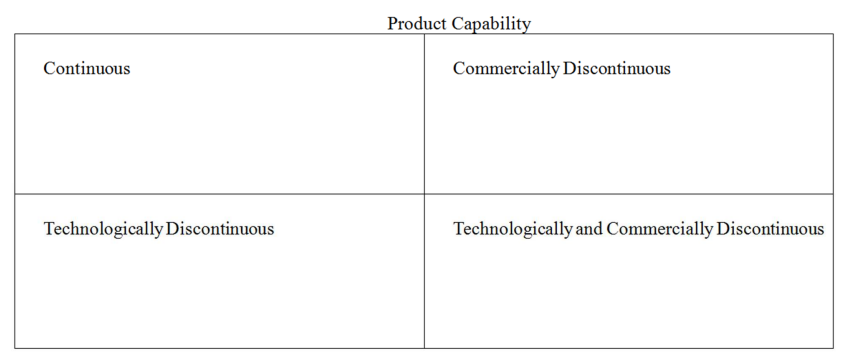

Figure 1. Types of Product Innovation (Veryzer, 1998).

\subsection{Theoretical Framework}

CRM has its evolutionary roots in the progression of relationship marketing and the great amount of attention given to improving customer retention through the effective management of customer relationships [45]. Relationship marketing was introduced in the service marketing by Leonard Berry in 1983 and its goal was to retain customers for the organization and satisfy them rather than a focus on sales and transactions [35]. The Commitment-Trust Theory of relationship marketing will be the focus in this study.

The Commitment-Trust theory of relationship marketing states that for a relationship to be successful in a business, two fundamental factors must exist: "Trust and Commitment" [74]. Relationship marketing involves forming bonds with customers by meeting their needs and honouring commitments. Rather than chasing short-term profits, businesses following the principles of relationship marketing forge long-lasting bonds with their customers. As a result, customers trust these businesses, and the mutual loyalty helps both parties fulfill their needs [37].

Trust is the confidence both parties in the relationship have that the other party will not do something harmful or risky [74]. Businesses develop trust by standing behind their promises. Commitment on the other hand involves a longterm desire to maintain a valued partnership [74]. That desire according to Brink and Berndt [62] causes the business to continually invest in developing and maintaining relationships with its customers. For example, a business might follow up after a purchase to ensure a customer was satisfied with her experience. If not, the business might refund the customer or offer a discount on her next purchase. Further, the business could incorporate the feedback to ensure that other customers do not have the same bad experience. In other words, through a series of relationshipbuilding activities, the business shows its committment to the customer [54, 35]. According to [62], the results of a relationship based commitment and trust are cooperative 
behaviours that allow both parties to fulfill their needs. Customers not only get the product or service they are paying for, but they also feel valued. The business receives customer loyalty in return, which is valuable, because the organization will not have to waste resources acquiring new customers. In other words, investing money in excellent customer service actually can save the organization money, because the organization will ot have to invest in, for example, numerous marketing campaigns to obtain new customers [74].

\section{Methodology}

This study employed survey research design. Data were obtained through questionnaire. The survey research involves gathering of data from selected sample drawn from the entire population to meet the research objective. The population consist of (105) members of staff of Xerox H. S (Nigeria) Limited in Lagos and Abuja as at February 2019.

\subsection{Sample Size Determination}

The sample size for the study is eighty three (83), this was arrived at using Taro Yamani formula as follows;

$$
\frac{N}{1+N(e) 2}
$$

Where $\mathrm{N}=$ population

$1=$ constant

$\mathrm{e}=$ error of margin $(5 \%)$ that is 0.05

$$
\begin{aligned}
& \frac{105}{1+105(0.05) 2} \\
& \frac{105}{1+105(0.0025)}
\end{aligned}
$$

$$
\begin{gathered}
\frac{105}{1+(1.2625)} \\
\frac{105}{1.2625}
\end{gathered}
$$

$\mathrm{S}=83.168$

$\mathrm{S}=83$

\subsection{Data Collection}

The data were collected by self-administered questionnaire with the help of staff assistants. The unit of analysis for this study is employees who are male and female respondents. The questionnaire is a close ended type that consisted of multiple choice questions which allow the respondents to make quick decisions using five-point multiple choice ordinal Likert scale.

\subsection{Data Analysis}

Data obtained from the questionnaires administered to the respondents were analyzed with the aid of Statistical Package for Social Sciences (SPSS) version 25 to find out the nature of the relationship between CRM and product innovation. The techniques of analysis used is regression.

\subsection{Model Specification}

The regression model for the analysis is:

$$
Y=a+\beta_{1} X_{1}+\beta_{2} X_{2}+\beta_{3} X_{3} \ldots(+e)
$$

$\mathrm{Y}=$ Product innovation

$\mathrm{A}=$ Intercept (value of $\mathrm{y}$ when $\mathrm{Xj}$ is zero)

$B_{j}=$ Regression weight attached to the variables $j(j=1,2,3)$

$\mathrm{X}_{1}=$ Customer information management

$\mathrm{X}_{2}=$ Customer segment value management

$\mathrm{X}_{3}=$ Multi-channel management

\section{Analysis and Findings}

Table 1. Descriptive analysis of Customer Information Management (CIM).

\begin{tabular}{llllllllll}
\hline Customer Information Management (CIM) & SD & D & SA & A & SA & Total & Mean & STD \\
\hline We collect customer information on a & No & 0 & 7 & 20 & 22 & 30 & 79 & 3.95 & 1.00 \\
regular basis. & $\%$ & 0.00 & 8.86 & 25.32 & 27.85 & 37.97 & 100.00 & \\
We capture customer information from & No & 0 & 12 & 20 & 21 & 26 & 79 & 3.77 & 1.07 \\
internal sources within the organization. & $\%$ & 0.00 & 15.19 & 25.32 & 26.58 & 32.91 & 100.00 & & \\
We use customer interactions to collect & No & 0 & 8 & 24 & 21 & 26 & 79 & 3.82 & 1.01 \\
information. & $\%$ & 0.00 & 10.13 & 30.38 & 26.58 & 32.91 & 100.00 & & \\
\hline
\end{tabular}

Source: Researcher field survey data, 2019.

As shown in Table 1, three statements were used to measure customer information management. In Table 1, strongly disagree, disagree, slightly agree, agree and strongly agree are represented by $\mathrm{SD}, \mathrm{D}, \mathrm{SA}, \mathrm{A}, \mathrm{SA}$ respectively. Also, mean and standard deviations for the variables are represented by Mean and STD respectively. Table 1 indicates that by combining responses under slightly agree, agree and strongly agree, $72(91 \%)$ of the respondents revealed that they collected customer information on an ongoing basis. 67
$(84.81 \%)$ agreed that they capture customer information from internal sources within the organization and $71(89.87 \%)$ indicated that they use customer interactions to collect information.

The perception of respondents on customer information management also show that, "We collect customer information on an ongoing basis" had respondents responding with a mean value of 3.95 and standard deviation of 1.00. Also, the question "We capture customer information 
from internal sources within the organization" revealed a mean value of 3.77 and standard deviation of 1.07 by the respondents, whiles the question "We use customer interactions to collect information" has a mean values of 3.82 and standard deviation of 1.01 .

Table 2. Descriptive analysis of Customer Segment Value Management (CSVM).

\begin{tabular}{lllllllll}
\hline Customer Segment Value Management (CSVM) & SD & D & SA & A & SA & Total & Mean & STD \\
\hline We use customer information to segment & No & 0 & 6 & 15 & 31 & 27 & 79 \\
markets & $\%$ & 0.00 & 7.59 & 18.99 & 39.24 & 34.18 \\
We use customer information to & No & 0 & 7 & 22 & 22 & 28 & 100.00 \\
customize our offers. & $\%$ & 0.00 & 8.86 & 27.85 & 27.85 & 35.44 & 100.00 \\
We use customer information to assess & No & 0 & 8 & 15 & 27 & 29 & 79 \\
the lifetime value of our customers. & $\%$ & 0.00 & 10.13 & 18.99 & 34.18 & 36.71 \\
\hline
\end{tabular}

Source: Researcher field survey data, 2019.

As shown in Table 2, three statements were used to measure customer segment value management. In Table 2, strongly disagree, disagree, slightly agree, agree and strongly agree are represented by $\mathrm{SD}, \mathrm{D}, \mathrm{SA}, \mathrm{A}, \mathrm{SA}$ respectively. Also, mean and standard deviations for the variables are represented by Mean and STD respectively. Table 2 indicates that by combining responses under slightly agree, agree and strongly agree, $73(92.41 \%)$ of the respondents revealed that they use customer information to segment markets. 72 (91.14\%) agreed that they use customer information to customize our offers and 71 (89.87\%) indicated that they use customer information to assess the lifetime value of our customers.

The perception of respondents on customer segment value management also show that the question; "We use customer information to segment markets" had respondents responding with a mean value of 4.00 and standard deviation of 0.92 . Also, the question; "We use customer information to customize our offers" revealed a mean value of 3.90 and standard deviation of 0.99 by the respondents, whiles the question; "We use customer information to assess the lifetime value of our customers" has a mean values of 3.97 and standard deviation of 0.99 .

Table 3. Descriptive analysis of Multi-Channel Management (MCM).

\begin{tabular}{|c|c|c|c|c|c|c|c|c|c|}
\hline Multi-Channel Management (MCM) & & SD & D & $\mathbf{S A}$ & $\mathbf{A}$ & $\mathbf{S A}$ & Total & Mean & STD \\
\hline We enable our customers to have & No & 0 & 6 & 21 & 24 & 28 & 79 & 3.94 & 0.97 \\
\hline interactive communications with us. & $\%$ & 0.00 & 7.59 & 26.58 & 30.38 & 35.44 & 100.00 & & \\
\hline We provide our customers with multiple & No & 0 & 1 & 17 & 29 & 32 & 79 & 4.16 & 0.81 \\
\hline We focus on communicating periodically & No & 0 & 4 & 22 & 28 & 25 & 79 & 3.94 & 0.90 \\
\hline with our customers. & $\%$ & 0.00 & 5.06 & 27.85 & 35.44 & 31.65 & 100.00 & & \\
\hline
\end{tabular}

Source: Researcher field survey data, 2019.

As shown in Table 3, three statements were used to measure multi-channel management (MCM). In Table 3, strongly disagree, disagree, slightly agree, agree and strongly agree are represented by $\mathrm{SD}, \mathrm{D}, \mathrm{SA}, \mathrm{A}, \mathrm{SA}$ respectively. Also, mean and standard deviations for the variables are represented by Mean and STD respectively. Table 3 indicates that by combining responses under slightly agree, agree and strongly agree, $73(92.41 \%)$ of the respondents revealed that they enable their customers to have interactive communications with them. $78(98.73 \%)$ agreed that they provide their customers with multiple ways to contact the organization and $75(94.94 \%)$ indicated that they focus on communicating periodically with their customers.

The perception of respondents on multi-channel management also show that the question; "We enable our customers to have interactive communications with us" had respondents responding with a mean value of 3.94 and standard deviation of 0.97 . Also, the question; "We provide our customers with multiple ways to contact the organization revealed a mean value of 4.16 and standard deviation of 0.81 by the respondents, whiles the question; "We focus on communicating periodically with our customers" has a mean values of 3.94 and standard deviation of 0.90 .

Table 4. Descriptive analysis of Product Innovation (PI).

\begin{tabular}{|c|c|c|c|c|c|c|c|c|c|}
\hline Product Innovation (PI) & & SD & D & $\mathbf{S A}$ & $\mathbf{A}$ & SA & Total & Mean & STD \\
\hline In our business, customers' product preferences change & No & 2 & 12 & 15 & 34 & 16 & 79 & 3.63 & 1.05 \\
\hline substantially over time. & $\%$ & 2.53 & 15.19 & 18.99 & 43.04 & 20.25 & 100.00 & & \\
\hline We are witnessing demand for our products and services & No & 3 & 9 & 19 & 27 & 21 & 79 & 3.68 & 1.10 \\
\hline A large number of new product ideas have been made & No & 1 & 10 & 25 & 22 & 21 & 79 & 3.66 & 1.05 \\
\hline possible through $\mathrm{t}$ customer interactions & $\%$ & 1.27 & 12.66 & 31.65 & 27.85 & 26.58 & 100.00 & & \\
\hline
\end{tabular}

Source: Researcher field survey data, 2019. 
As shown in Table 4, three statements were used to measure product innovation (PI). In Table 4, strongly disagree, disagree, slightly agree, agree and strongly agree are represented by $\mathrm{SD}, \mathrm{D}, \mathrm{SA}, \mathrm{A}, \mathrm{SA}$ respectively. Also, mean and standard deviations for the variables are represented by Mean and STD respectively. Table 4 indicates that by combining responses under slightly agree, agree and strongly agree, $65(82.28 \%)$ of the respondents revealed that in their business, customers' product preferences change substantially over time. $67(84.81 \%)$ agreed that they are witnessing demand for their products and services from customers who never bought them before and 68 (86.08\%) indicated that there is a large number of new product ideas have been made possible through customer interactions.

The perception of respondents on product innovation also show that the question; "In our business, customers' product preferences change substantially over time" had respondents responding with a mean value of 3.63 and standard deviation of 1.05. Also, the question; "We are witnessing demand for our products and services from customers who never bought them before" has a mean values of 3.68 and standard deviation of 1.10, whiles the question; "A large number of new product ideas have been made possible through $t$ customer interactions" has a mean values of 3.66 and standard deviation of 1.05 .

\subsection{Test of Hypothesis}

This study carried out a Pearson correlation analysis at 5\% level of significance and the results were presented in the Table 5 to determine the relationship between the study variables.

Table 5. Correlation Analysis.

\begin{tabular}{|c|c|c|c|c|c|}
\hline & & CIM & CSVM & МCM & PI \\
\hline \multirow[t]{2}{*}{ CIM } & $\begin{array}{l}\text { Pearson Correlation } \\
\text { Sig. (2-tailed) }\end{array}$ & 1 & & & \\
\hline & $\mathrm{N}$ & 79 & & & \\
\hline \multirow{3}{*}{ CSVM } & Pearson Correlation & $.601^{* *}$ & 1 & & \\
\hline & Sig. (2-tailed) & .000 & & & \\
\hline & $\mathrm{N}$ & 79 & 79 & & \\
\hline \multirow{2}{*}{ MCM } & Pearson Correlation & $.722^{* *}$ & $.619^{* *}$ & 1 & \\
\hline & $\mathrm{N}$ & 79 & 79 & 79 & \\
\hline \multirow{3}{*}{ PI } & Pearson Correlation & $.761^{* *}$ & $.632^{* *}$ & $.734^{* *}$ & 1 \\
\hline & Sig. (2-tailed) & .000 & .000 & .000 & \\
\hline & $\mathrm{N}$ & 79 & 79 & 79 & 79 \\
\hline
\end{tabular}

**. Correlation is significant at the 0.01 level (2-tailed).

Note: $\mathrm{CIM}=$ customer information management, $\mathrm{CSVM}=$ customer segment value management, $\mathrm{MCM}=$ multi-channel management and $\mathrm{PI}=$ product innovation.

The findings on Table 5 above reveals that customer information management has a positive significant effect on product innovation $(\mathrm{r}=0.761$, $\mathrm{P}$-value $=0.000)$. This reveals that an increase in customer information management increases product innovation. The results also showed that the association between customer segment value management and product innovation is positive and significant $(\mathrm{r}=0.632, \mathrm{P}$-value $=0.000)$ which reveals that an increase in customer segment value management leads to an increase product innovation. Lastly, the correlation findings also showed that multi-channel management has a positive and significant association with product innovation ( $\mathrm{r}=0.632$, $\mathrm{P}$-value $=0.000)$. This shows that when the there is an increase in the multi-channel management, product innovation will also increase.

\subsubsection{Regression Analysis}

Effect of customer relationship management on product innovation in Xerox H. S (Nigeria) Limited was established using an ordinary regression analysis. Regression analysis involved the analysis of coefficient of determination, model significance and model coefficients.

\subsubsection{Coefficient of Determination}

Coefficient of determination was used to show the changes in product innovation which can be attributed to customer relationship management dimensions such as customer information management, customer segment value management and multi-channel management. The regression analysis results presented in Table 5 indicates that the coefficient of determination ( $\mathrm{R}$ squared) was 0.669 which implies that $66.9 \%$ of the changes in product innovation is explained by customer relationship management dimensions such as customer information management, customer segment value management and multi-channel management. An adjusted $\mathrm{R}$ square value of 0.655 on the other hand revealed that $65.5 \%$ of the changes in product innovation are explained by only those variables with $\mathrm{P}$-value that is significant.

Table 6. Coefficient of Determination (Model Summary).

\begin{tabular}{lllll}
\hline Model & R & R Square & Adjusted R Square & Std. Error of the Estimate \\
\hline 1 & $.818^{\mathrm{a}}$ & .669 & .655 & .48591 \\
\hline
\end{tabular}

a. Predictors: (Constant), Customer segment value management, Customer information management, Multi-channel management. 


\subsubsection{Analysis of Variance (Model Significance)}

The study also established the model significance of the regression model linking customer relationship management to product innovationin Xerox H. S (Nigeria) Limited. The study findings in Table 6 revealed that the overall model was significant. The $\mathrm{F}$ statistic for the model of 50.449 was significant ( $\mathrm{Sig}=0.000$ ), hence it was concluded that the model linking customer relationship management to product innovationin Xerox H. S (Nigeria) Limited was significant.

To corroborate the findings, the study also used the F- distribution table to obtain the F-critical value $\left(\mathrm{F}_{0.05}(2.727)\right.$ calculated at $=5 \%$, using denominator degrees of freedom of 78 and numerator degrees of freedom of 3 and compared against the F-calculated value of 50.449. The rule of the thumb is that if F-calculated is greater than the F-critical, then the model is significant. The F-critical value from the Fdistribution table was 2.727 which is less than 50.449 hence it confirms the previous findings that the model linking customer relationship management to product innovationin Xerox H. S (Nigeria) Limited was significant.

Table 7. Analysis of Variance (Model Significance).

\begin{tabular}{llllll}
\hline Model & & Sum of Squares & Df & Mean Square & F \\
\hline \multirow{3}{*}{1} & Regression & 35.735 & 3 & 11.912 & 50.449 \\
& Residual & 17.708 & 75 & .236 & $.000^{\mathrm{b}}$ \\
& Total & 53.443 & 78 & & \\
\hline
\end{tabular}

a. Dependent Variable: Product innovation.

b. Predictors: (Constant), Customer segment value management, Customer information management, Multi-channel management.

\subsubsection{Model Coefficients}

Table 8. Coefficients.

\begin{tabular}{|c|c|c|c|c|c|c|}
\hline \multirow{2}{*}{ Model } & & \multicolumn{2}{|c|}{ Unstandardized Coefficients } & \multirow{2}{*}{$\begin{array}{l}\text { Standardized Coefficients } \\
\text { Beta }\end{array}$} & \multirow{2}{*}{$\mathbf{t}$} & \multirow{2}{*}{ Sig. } \\
\hline & & B & Std. Error & & & \\
\hline \multirow{4}{*}{1} & (Constant) & -.514 & .389 & & -1.322 & .190 \\
\hline & CIM & .418 & .099 & .424 & 4.235 & .000 \\
\hline & CSVM & .219 & .107 & .181 & 2.048 & .044 \\
\hline & MCM & .429 & .138 & .316 & 3.097 & .003 \\
\hline
\end{tabular}

a. Dependent Variable: Product Innovation.

Note: $\mathrm{CIM}=$ customer information management, $\mathrm{CSVM}=$ customer segment value management, $\mathrm{MCM}=$ multi-channel management and $\mathrm{PI}=$ product innovation.

From the results in table 8 above, the results show that taking all the other independent variables as constant, a unit increase in customer information management will result in a 0.418 increase in product innovation. Similarly, a unit increase in customer segment value management, assuming all other factors are held constant resulted in a 0.219 increase in product innovation and a unit increase in multi-channel managementwill result in a 0.429 increase in product innovation. Moreover, customer information management, customer segment value management and multi-channel management all have a positive significant effect on product innovation as shown by a high $t$ value and a $p$ value that was less than 0.05 . The following regression equation was estimated (2):

$$
\mathrm{Y}=-0.514+0.418 \mathrm{X}_{1}+0.219 \mathrm{X}_{2}+0.429 \mathrm{X}_{3}+\varepsilon
$$

Where, $\mathrm{Y}=$ Product innovation (Product innovation)

$\mathrm{X}_{1}=$ Customer information management

$\mathrm{X}_{2}=$ Customer segment value management

$\mathrm{X}_{3}=$ Multi-channel management

On the estimated regression model above, the constant=0.514 shows that if selected independent variables (Multichannel management, customer information management and customer segment value management) were rated zero, product innovation would be -0.514 .

\subsection{Discussion of Findings}

The overall objective of this study was to examine the effect of customer relationship management on product innovation in Nigeria with emphasis on Xerox H. S (Nigeria) Limited. Specifically, the first objective of the study was to ascertain the effect of customer information management on product innovation. The regression test results indicated that customer information management has a significant positive effect on product innovation. This implies that the end goal of CIM is to order all of the information that a business has about customers in any part of its software architecture, breaking down data silos, so that the business has the best intelligence and benefits the most from its data assets. One of such benefits could include product innovation. The finding of this study in terms of customer segment value management supports the conclusion of Jayachandran et al. [11] showed that the existence of the customer centric information processes increases CRM performance which in turn improves product innovation.

The second objective of the study was to ascertain the effect of customer segment value management on consumer product innovation. The regression coefficient indicated that, an increase in customer segment value managementhas a positive effect on product innovation. This result may be explained by the fact that a key aspect of CRM is to differentiate between customer segments and to customize 
marketing activities to these segments [22]. In the context of existing products, this typically involves segmenting customers with regard to their respective sales and/or profit potential [22]. In the context of new products, however, this aspectof CRM needs to be extended. The finding of this study that customer segment value management has a positive effect on product innovationis further supported by previous research which indicates that aligning the product innovation process with these valuable customers' requirements increases new product performance [53].

The third objective of the study was to ascertain the effect of multi-channel management on product innovation. The regression test results indicated that Multi-channel management has a significant positive effect on product innovation. This illustrates that any efforts of increasing multi-channel management would see product innovationsignificantly increase. This result is explained by the fact that each customer contactpoint provides the opportunity to gain valuable information and to build a customer relationship. If information is collected and shared across multiple channels, firms and customers have the opportunity to choose an appropriate communication channel for a specific purpose.

In thecontext of product innovation, multi-channel management allows the firm to use a variety of channels to contact different segments of customers for a specific task. Thus, multi-channel management as part of CRM increases the opportunity for a firm to collect more valuable information for product innovation from customers. Using multiple channels will therefore help to provide more detailed customer input into the product innovation process. This leads to higher new product performance on the market. In terms of Multi-channel management, the finding of this study is similar to other studies such as Boulding et al. [21] who concluded that multiple communication channels enable companies to collect information and interact with valued customers more effectively in a variety of ways.

\section{Conclusion}

The study sought to establish the effect of customer relationship management on product innovation in Nigeria, with emphasis on Xerox H. S (Nigeria) Limited. Specifically, the study was guided by the following objectives; to ascertain the effect of customer information management on product innovation; to ascertain the effect of customer segment value management on consumer product innovation; and to ascertain the effect of multi-channel management on product innovation. The research design method used in this study is survey research designs. The data obtained was analyzed using quantitative analysis. Multiple regression models were used to test whether the customer segment value management, customer information management and multichannel management have any effect on product innovation.

The findings of this study linking customer information management with product innovation revealed a significant positive effect. Implying that, product innovation to a large extend depends on the level of customer information management. Similarly, the results also linked customer segment value management to product innovation significantly revealed that high level of customer segment value managements were associated with aincrease in product innovation. Furthermore, findings also indicated that multi-channel management has a positive and significant effect on product innovation, implying that when the there is an increase in multi-channel management, product innovation also increases but significantly.

\section{Recommendations}

First, it is recommended that, businesses should embark on building a stronger CRM capability since it has been established that it contributes significantly to product innovation. Firms in order to meet or possibly exceed their planned performance should in general put customers first in order to ensure greater knowledge about them to be able to satisfy their needs.

Furthermore, Communication is a key concept in the improvement of customer relationship management and its capabilities. The way firms communicate or share informationwith its actual and potential customers can become a strong capability for the firm that is going to provide the business with greater competitive advantage. Formal or informal training on effective communication skills must be embarked on for the owners and managers of businesses. The academic community can be of immense help in this direction.

CRM provides companies with a promising way to attack its critical problem. In order to do so, however, it is critical that managers adopt a broader perspective on CRM (beyond just relationship management). Multiple CRM processes such as customer segment value management and multi-channel management need to be considered. In other words, firms need to collect information fromCRM processes, use it to identify and understand valuedcustomers (such as lead users and opinion leaders), and use multiple channels to acquire input into product innovation processes.

When distributing a product, each "channel" is an additional avenue to reach customers. Thus, multi-channel distribution management is a strategy to provide customers with multiple ways to purchase the same product.

The study also recommends that since multi-channel management has a significant positive effect on product innovation, When designing and implementing a multi channel strategy, objectives and goals of internal and external parties affected by the multi channel approach should be considered.

\section{Suggestions for Further Studies}

The study used only one company in Nigeria. A similar study should be done on firms which are listed on the Nigeria Stock Exchange and determine if the same results would be achieved. This study also suggests that more effort be made 
into exhaustively exploring the conceptual and technological framework of customer relationship management. More critical factors can be analysed and a systematic view of those factors will be helpful in practical terms. Another possible research direction is to utilize more dimensions of customer relationship management. This may require a more comprehensive understanding of business nature. A longer investigation time frame is also needed.

\section{References}

[1] Rosenbrook, T. (2015). Five reasons why the customer is king, article published in https://www.techtarget.com and accessed on the $27^{\text {th }}$ September, 2018.

[2] Berfenfeldt, J. (2010). Customer Relationship Management, Master Thesis, Department of Business Administration and Social Sciences, Lulea University of Technology, Sweden.

[3] Robles, P. (2015). The five biggest benefits of CRM systems, article published at https://www.econsultancy.com and accessed on the $11^{\text {th }}$ September, 2018.

[4] Jim, B. (2008). Essentials of Marketing, $4^{\text {th }}$ Edition, NY: Pearson Education.

[5] Sally, L. (2007). Sam Walton: Business Genius of Wal-Mart. Enslow Publishers Inc. p. 13.

[6] Murcko, M. (2012). 6 reasons why the customer is important, article published at https://www.marketingteacher.com and accessed on the $23^{\text {rd }}$ September, 2018.

[7] Walden, S. (2013). The importance of cultivating customer relationship in business, article published at https://www.mashable.com and accessed on the $27^{\text {th }}$ September, 2018.

[8] Dowling, G. W. (2002), “Customer Relationship Management: In B2C Markets, Often Less Is More, "California ManagementReview, 44 (Spring), 87-104.

[9] Rouse, M. (2012). Customer relationship management, article published at https://www.techtarget.com and accessed on the $27^{\text {th }}$ September, 2018.

[10] Boateng, A. I (2014). Effects of customer relationship management on product innovation of banking services in Ghana, article published in Journal of contemporary integrative ideas, volume 2. Issue no. 1.

[11] Jayachandran, S., Sharma, S., Kaufman, P., \& Raman, P. (2005). The role of relational information processes and technology use in customer relationship management. Journal of Marketing, 69 (4), 177-192.

[12] Dougherty D. 1992. A practice-centered model of organizational renewal through product innovation. Strategic Management Journal, Summer Special Issue 13: 77-92.

[13] Bowen, H. K; Clark, K. B; Holloway, C. A; \& Wheelwright, S. C. (1994). Development projects: the engine of renewal. Harvard Business Review 72 (5): 110-120.

[14] Womack, J. P., D. T; \& D. R. Roos (1990) The Machine That Changed the World: The Story of Lean Production, New York: Harper Perennial.
[15] Burgelman, R. A. (1991) "Intraorganizational ecology of strategy making and organizational adaptation: Theory and field research, "Organization Science, 2: 239-262.

[16] Srivastava, Raj, TassaduqShervani, \& Liam Fahey (1998), "Marketing-Based Assets and Shareholder Value: A Framework for Analysis, "Journal of Marketing, 62 (January), 2-18.

[17] Kerstetter, J. (2001), "Software Highfliers, " BusinessWeek, (June18), 108-109.

[18] Reinartz, W., \& Kumar, V. (2002). The impact of customer relationship characteristics on profitable lifetime duration. Journal of Marketing, 67 (1), 77-99.

[19] Winer, R. (2001). A framework for customer relationship management. California Management Review, 43, 89-105

[20] Morgan, R. M. \& Hunt, S. D. (1994), "The CommitmentTrust Theory of Relationship Marketing, "Journalof Marketing”, 58 (July), 20-38.

[21] Boulding, W., Staelin, R., Ehret, M., \&Johnston, W. J. (2005). A customer relationship management roadmap: what is known, potential pitfalls, and where to go. Journal of Marketing, 69 (4), 155-166.

[22] Reinartz, W., Krafft, M., \& Hoyer, W. D. (2004). The customer relationship management process: its measurement and impact on performance. Journal of Marketing Research, 41 (3), 293-305.

[23] Payne, A., \&Frow, P. (2005). A strategic framework for customer relationship management. J Mark, 69 (4), 167176.

[24] Parvatiyar, A., \&Sheth, J. N. (2000). The domain and conceptual foundations of relationship marketing. In J. N. Sheth\& A. Parvatiyar (Eds.), Handbook of relationship marketing (pp. 3-38). Thousand Oaks: Sage.

[25] Ryals, L. \& Payne (2001). Making customer relationship management work: the measurement and profitable management of customer relationships. J Mark, 69 (4), 252261.

[26] Zablah, A. R.; Dany, N. B. \& Wesley, J. J (2003), Customer relationship management: An Explication of its decision and avenues for further inquiry, in relationship marketing, customer relationship management and marketing management: cooperation-competition-co-evolution, Michael Kleinaltenkamp\& Michael Ehret, eds Berlin: Freie Universitat Berlin, 115-24.

[27] Rust, R. T., Zeithaml, V. A., \& Lemon, K. N. (2000). Driving customer equity; how customer lifetime value is reshaping corporate strategy. New York: The Free.

[28] Blattberg, R. C., Getz, G., \& Thomas, J. S. (2001). Customer equity: Building and managing relationships as valuable assets. Boston: Harvard Business School.

[29] Abernathy, W. J and Utterback, J. M (2008). Patterns of industrial innovation, In: Readings in the Management of Innovation, $2^{\text {nd }}$ edition, Michael Tushan and William Moore (eds.). New York, Harper Business, pp 25-36.

[30] Ali, A. (2004). Pioneering versus incremental innovation: Review and research propositions. Journal of product innovation management. 
[31] Voss, G. B., \& Voss, Z. G. (2008). Competitive density and the customer acquisition-retention trade-off. Journal of Marketing, 72 (6), 3-18.

[32] Ramani, G., \& Kumar, V. (2008). Interaction orientation and firm performance. Journal of Marketing, 72 (1), 27-45.

[33] Thomas, J. S., Blattberg, R. C., \& Fox, E. J. (2004). Recapturing lost customers. Journal of Marketing Research, 41 (1), 31-45.

[34] Sin, L. Y. M., Tse, A. C. B., \&Yim, F. H. K. (2005). CRM: conceptualization and scale development. European Journal of Marketing, 39 (11/12), 1264-1290.

[35] Dowling, G. W \& Uncles, M. (1997), "Do Customer Loyalty Programs Really Work?" Sloan Management Review, 38 (Fall), 71-82.

[36] Henneberg, Stephan C. M. (2003), "An Exploratory Analysis of CRM Implementation Models, " paper presented at the $11^{\text {th }}$ International Colloquium in Relationship Marketing, University of Gloucestershire.

[37] Khanna, S. (2001), "Measuring the CRM ROI: Show Them Benefits," (accessed November 20, 2002), [available at http://www.crm-forum.com].

[38] Stone, M. \& Neil W. (2001), "Defining CRM and Assessing its Quality, " in Successful Customer RelationshipMarketing, Brian Foss and Merlin Stone, eds. London: Kogan Page, 3-20.

[39] Singh, J. \&Agrawal (2003), "Voice, Exit, and Negative Wordof-Mouth Behaviors: An Investigation Across Three Service Categories, "Journal of the Academy of Marketing Science, 18 (Winter), 1-15.

[40] Galbraith, J. (1973). Designing complex organizations. Reading, MA: Addison-Wesley.

[41] Buttle, F. (2004). Customer Relationship Management: Concepts and tools, Oxford: Elsevier.

[42] Gosney, J. \& Boehm, T. (2000), Customer Relationship Management Essentials. Indianapolis, IN: Prima Publishing.

[43] Peppers, D., Rogers, M., \&Dorf, B. (1999). Is your company ready for one-to-one marketing? Harv Bus Rev, 77, 3-12.

[44] Hobby, J. (1999), "Looking After the One Who Matters, " Accountancy Age, (October 28), 28-30.

[45] Glazer, Rashi (1997), "Strategy and Structure in InformationIntensive Markets: The Relationship Between Marketing and IT, "Journal of Market Focused Management, 2 (1), 65-81.

[46] Madhavan, R., \& Grover, R. (1998). From embedded knowledge to embodied knowledge: new product development as knowledge management. J Mark, 62 (4), 112

[47] Swift, Ronald S. (2000), Accelerating Customer Relationships-Using CRM and Relationship Technologies. Upper SaddleRiver, NJ: Prentice Hall.

[48] Jaworski, B. J., \&Kohli, A. K. (1993). Market orientation: antecedents and consequences. J Mark, 57 (3), 53-70.

[49] Von Hippel, E. (1986). Lead users: source of novel product concepts. Manag Sci, 32 (7), 791-805.

[50] Von Hippel, E. (1994). Sticky information and the locus of problem solving: implications for innovation. ManagSci, 40 (4), 429-439.

[51] Lilien, G. L., Morrison, P. D., Searls, K., Sonnack, M., \& Von Hippel, E. (2002). Performance assessment of the lead user idea-generation process for new product development. Management Sci, 48 (8), 1042-1059.

[52] Gruner, K., \& Homburg, C. (2000). Does customer interaction enhance new product success? J Bus Res, 49 (1), 1-14.

[53] Childers, T. L. (2006). Assessment of the psychometric properties of an opinion leadership scale. J Mark Res, 23 (2), 184-188.

[54] Sawhney, M. S., \&Prandelli, E. (2001). Beyond customer knowledge management: customers as knowledge co-creators. In Y. Malhotra (Ed.), Knowledge management and virtual organization (pp. 258-281). Hershey: Idea Group.

[55] Ryals, L. (2005). Making customer relationship management work: the measurement and profitable management of customer relationships. J Mark, 69 (4), 252-261.

[56] Grönroos, C. (2000). Service marketing and management: a customer relationship management approach (2nd ed.). New York: Wiley.

[57] Gales, L., \& Mansour-Cole, D. (1995). User involvement in innovation projects: towards an information processing model. J Eng Tech Manage, 12 (1/2), 77-109.

[58] Brown, S. A. (2000). Customer relationship management-a strategic imperative in the world of E-business. New York: Wiley.

[59] Smith, J. B. (1998). Buyer-seller relationships-similarity, relationship management, \& quality. Psychol Mark, 15 (1), 321

[60] Morrison, P. D., Roberts, J. H., \&Midgley, D. F. (2004). The nature of lead users and measurement of leading edge status. Res Policy, 33 (2), 351-362.

[61] Brink, A \& Berndt, A. (2007). Relationship marketing and customer relationship management, article published in Journal of relationship marketing, vol. 1 (13).

[62] Brown, S. L., \&Eisenhardt, K. M. (1995). Product development: past research, present findings, \& future directions. AcadManag Rev, 20 (2), 343-378.

[63] Schon, D. (1967) Technology and Change, Oxford, MA: Pergamon.

[64] Booz, Allen \& Hamilton (1982): new product management for the 1980's. New York.

[65] Olson, E. M; Orville, C. W; \& Robert, W. R (1995). Organising for effective new product development: the moderating role of product innovativeness. Journal of Marketing 59, 48-62.

[66] Day (1994). The capabilities of market-driven organization. Journal of Marketing 58. 37-52, 68.

[67] Day \& Robin, W. (2008). Assessing Advantage: A framework for diagnosing competitive superiority. Journal of Marketing $52,1-20$.

[68] Veryzer (1998). Discontinuous innovation and the new product development process. Elsevier Science Inc. 
[69] Bresson, C. \& Townsend, J. (2008). Multivariate models for innovation-looking at the Abernathy-Utterback model with other data. Omega 9: 429-436.

[70] Green, S. G.; Gavin, M. B \&Aiman-smith, L. (2005). Assessing a multidimensional measure of radical technical innovation. IEEE transactions on Engineering management 42 (3): 203.

[71] Nystrom, H. (2015). Product development strategy: An integration of technology and marketing. Journal of product innovation management $2: 25-33$.
[72] Crawford, C. M. (2004). New product management, $4^{\text {th }}$ ed. Boston: Richard and Irwin, Inc.

[73] Mack, S. (2013). The Coittmment-Trust theory of relationship marketing, article published in Journal of Relationship Marketing, volume 3, issue 2. 